\title{
Small, Stellate, or Spindled Cells Present
}

National Cancer Institute

\section{Source}

National Cancer Institute. Small, Stellate, or Spindled Cells Present. NCI Thesaurus. Code C159220.

A morphologic finding indicating the presence of small, stellate, or spindled cells in a cellular infiltrate. 